\title{
Dynamika nadlokálneho a lokálneho v každodennosti života na hranici (na príklade regiónu Kysuce) Ivana Kontriková Šusteková
}

DOI: 10.21104/CL.2021.3.04

The Dynamics of the Supralocal and the Local in Everyday Life on the Border (Based on the Example of the Kysuce Region)

\begin{abstract}
Border studies (currently also cross-border cooperation issues) is an interdisciplinary research specialization. The aim of the article is to present the spatial proximity influence of the state border on the everyday life reality of inhabitants of the Kysuce region in the 20th Century (overlapping with the present day) in both the local and supra-local context. With reference to the theory of the Irish sociologist Liam O'Dowd, it focuses on the Slovak state borders with Poland and the Czech Republic as a possible barrier, but also a bridge, a source of opportunities and a symbol of identity. It points out that in the villages bordering the Polish and Czech territories there has always been a relatively intensive mutual cultural transfer and contact of populations and therefore the borders cannot be perceived as an exclusively geopolitical phenomenon; their social and cultural dimension must be taken into account.
\end{abstract}

\section{Key words}

state border, the Kysuce region, 20th century, borders as a barrier, a bridge, a source of opportunities and a symbol of identity

\section{Contact}

doc. PhDr. Ivana Kontriková Šusteková, PhD., Katedra etnológie a folkloristiky, Filozofická fakulta, Univerzita Konštantína Filozofa v Nitre, Hodžova 1, 94974 Nitra, Slovakia; e-mail: iksustekova@ukf.sk.

ORCID iD https://orcid.org/0000-0001-9954-4144

Jak citovat / How to cite

Kontriková Šusteková, Ivana. 2021. Dynamika nadlokálneho a lokálneho v každodennosti života na hranici (na príklade regiónu Kysuce). Českýlid 108: 353-370. https://doi.org/10.21104/CL.2021.3.04 
Hranica, jej podoby, funkcie a premeny (v priestore a čase), kvalita života v prihraničných (pohraničných) regiónoch, ${ }^{1}$ intenzita a povaha kontaktov obyvatelstva žijúceho na oboch stranách štátnej hranice, miera ich kooperácie, prípadne segregácie stoja v pozornosti politických vied, geografie, ekonómie, historiografie, sociokultúrnej antropológie, etnológie, kulturológie, ale aj sociológie a iných spoločenskovedných disciplín. $\mathrm{V}$ nadväznosti na to variujú definície a prístupy $\mathrm{k}$ štúdiu hraníc. V politických vedách sa venuje pozornost' faktorom ovplyvňujúcim správanie a prijímanie rozhodnutí zo strany aktérov na národnej úrovni (vlády štátov zdielajúcich spoločnú hranicu) (Duleba et al. 2017: 5). Záujem geografov sa sústreduje na hranice ako dôležitý geografický fenomén, ktorý určuje rozdelenie a priestorové usporiadanie geografického prostredia, čím zároveň nepriamo vplýva na jeho celkový socioekonomický vývoj (Halás 2002: 49). V spoločenskovedných disciplínach sa pozornost' upriamila na otázky etnickej hranice, ktorá sa môže, ale nemusí zhodovat' so štátnou hranicou (napríklad F. Barth, T. H. Eriksen a d'alší). ${ }^{2}$

Cielom príspevku je predstavit' vplyv priestorovej blízkosti štátnej hranice na každodennú realitu života obyvatel'ov regiónu Kysuce v 20. storočí (s presahom do súčasnosti), a to v kontexte lokálneho i nadlokálneho. V intenciách teórie írskeho sociológa L. O'Dowda sa zameriava na hranice ako na zdroj možných konfliktov (vo vztahu k Polsku v prvých desatročiach minulého storočia, respektíve začiatkom 90 . rokov v dôsledku rozpadu Česko-Slovenska) aj ako na zdroj príležitostí (predovšetkým zárobkových pašovanie). Čiastkovým cielom je priblížit hranicu ako bariéru, ktorá oddeluje obyvatel'ov jednotlivých štátov, i priestor, kde dochádza k intenzívnym interlokálnym, interetnickým a interkultúrnym kontaktom. Hranici, ktorá v súčasnosti oddeluje Slovensko od Pol'ska a Česka, totiž možno pripísat' viaceré charakteristiky: štátna (v minulosti administratívna či krajinská), etnická, jazyková, kultúrna, geografická, historická, hospodárska, v istých dejinných etapách uzavretá či čiastočne uzavretá (v súčasnosti otvorená).

Práve blízkost' hraníc s Pol'skom a Českom umožnila časti obyvatel'stva rozvinút stratégie zaobstarávania si obživy, respektíve peňažných príjmov či vzácneho, nedostatkového alebo lacnejšieho tovaru, ktoré vo vnútroštátnych regiónoch absentovali alebo boli menej rozšírené. Napríklad znalosti spojené s pašovaním sa v niektorých rodinách dedili po generácie, čím sa vytvárala rodinná i lokálna tradícia, v niektorých obdobiach či ge-

1 Pojmy „prihraničný“ a „pohraničný“ používame ako synonymá.

$2 \mathrm{Na}$ Slovensku sa táto problematika riešila v dielach historikov, etnológov, humánnych geografov, sociológov a iných, napríklad L. Szarku, Š. Šutaja, E. Mannovej, G. Kiliánovej, M. Leščáka, K. Popelkovej, M. Vrzgulovej, M. Botikovej, M. Benžu, J. Maja, D. Kusendovej, V. Bačovej. 
neráciách prežívajúca latentne, inokedy znovuoživená (najmä v dôsledku zlomových historicko-spoločenských zmien). Hranice sú tým, čo nemusí zákonite rozdel'ovat', ale môže spájat' obyvatel'ov rôznych štátnych útvarov (ich prihraničných regiónov). Je to zjavné aj v súčasnosti v súvislosti s viacerými rozvojovými projektmi Európskej únie a programami cezhraničnej spolupráce (v prípade Kysúc najmä Interreg Pol'sko-Slovensko a Interreg Slovenská republika-Česká republika).

Avšak blízkost' hranice mohla aj negatívne zasiahnut do života obyvatel'ov pohraničných obcí - najmä po roku 1918 (1920) a 1938/1939, teda v období, ked' hranice neplnili iba funkciu demarkačných línií medzi jednotlivými (konštituujúcimi sa) štátmi, ale sa stali príčinou ich územných konfliktov (nárokov). Aj sprísnenie režimu na československo-pol'ských hraniciach po roku 1948 malo za následok spretŕhanie niekdajších rodinných, príbuzenských a iných väzieb, ale zároveň viedlo k revitalizácii postupov, ktoré pomáhali obíst' tieto reštrikcie. Podobne po rozdelení Česko-Slovenska v roku 1993 došlo k obmedzeniu dovtedy volného pohybu tovaru a osôb medzi novovznikajúcimi štátnymi útvarmi, čo vo viacerých obciach na slovensko-moravskom pomedzí spôsobilo problémy nielen členom zo "zmiešaných" (slovensko-českých) rodín, ludom dochádzajúcim za prácou do krajiny na opačnej strane hranice, ale aj majitel'om nehnutel'ností, ktoré sa ocitli na cudzom štátnom území. Spomenút možno aj situáciu, ktorá nastala v rokoch 2020-2021 v súvislosti so šírením pandémie COVID-19, ked" sa takzvaní „pendleri“ (cezhraniční zamestnanci) a záujemci o nákup lacnejšieho tovaru usilovali obíst' sprísnený režim na hraniciach s Českom a Pol'skom využívaním menej frekventovaných (neoficiálnych) hraničných priechodov, kde nepredpokladali výskyt policajných či pohraničných hliadok. Aj na tieto aspekty aspoň okrajovo upozorňuje prítomný článok.

Ťažisko získavania údajov k sledovanej problematike spočívalo v štúdiu odbornej literatúry a archívnych prameňov (Štátny archív v Žiline, pobočka Čadca - fondy Okresný úrad Čadca a Okresný úrad v Kysuckom Novom Meste), doplnených o údaje získané etnologickým terénnym výskumom, ktorý sa realizoval v obciach Nesluša, Krásno nad Kysucou, Čadca-Horelica, Čierne, Svrčinovec a Oščadnica. Išlo o sériu krátkodobých výskumov uskutočnených v rokoch 2001, 2002, 2007, 2008, 2017 a 2020 metódou volného (neštandardizovaného) rozhovoru. Oslovených bolo devät' respondentov (štyria muži narodení v rokoch 1924, 1932, 1941 a 1969 a pät žien narodených v rokoch 1923, 1928, 1932, 1956 a 1977). Vo väčšine prípadov (pät' z deviatich oslovených) nebola problematika života na hranici ústredným motívom rozhovorov, ale sekundárnou témou. Pri reflektovaní súčasnej situácie na hraniciach s Českom a Pol'skom sa využili aj informácie získané zo sociálnych sietí, diskusných fór a tlače. 
Z odbornej literatúry, venovanej skúmanej problematike, možno spomenút štúdiu G. Kiliánovej Vzt'ah lokálneho spoločenstva k štátu a jeho odraz v hierarchii hodnôt (na príklade pašovania cez hranicu) (1992), ktorá sa venovala pašovaniu na slovensko-rakúskych hraniciach, a I. Šustekovej Pašovanie ako špecifické doplnkové zamestnanie na Kysuciach v prvej polovici 20. storočia (2008). Konfliktu na slovensko-polských hraniciach koncom 30. rokov, ktorý vyústil do dočasného zabratia časti Kysúc Pol'skom, sa venovali práce L. Hallona et al. Kysuce v 20. storočí (2012), P. Matulu Školské a cirkeoné pomery na Kysuciach odstúpených Polsku v roku 1938 (2012), M. Janíka et al. Kysuce 1938 - 1945 (2015), ako aj viaceré články a výskumné správy I. Žilinčíka, niekdajšieho historika Kysuckého múzea v Čadci. V prípade teoretických aspektov výskumu hraníc bola inšpiratívna publikácia A. Dulebu et al. Hranice a cezhraničná spolupráca. Úvod do výskumu hraníc (2017). Za klúčovú považujeme aj štúdiu L. O'Dowda The Changing Significance of European Borders (2002), ktorého štvordimenzionálna koncepcia štátnej hranice sa stala tažiskovou pre prítomný článok (s akcentom na hranicu ako bariéru a zdroj príležitostí).

L. O'Dowd (2002:13-36) ako predstavitel' pragmatického prístupu k štúdiu hraníc poukazuje na to, že hranice európskych krajín sa často menili, pričom sa menili aj ich funkcie a význam. V tejto súvislosti píše o štyroch základných dimenziách štátnych hraníc, ktorých významy sa môžu prekrývat alebo si protirečit'. Hranicu vníma ako: bariéru (základná funkcia medzištátnych hraníc - regulovaná hranica s kontrolovaným cezhraničným pohybom, hranica ako prekážka integrácie); most (hranica umožňuje cezhraničnú spoluprácu na úrovni lokálnych politických, administratívnych a obchodných elít; cezhraničné projekty prehlbujú vzájomnú interakciu); zdroj príležitostí (hranica ako zdroj prospechu - cezhraničný obchod, respektíve nelegálne pašovanie) a symbol identity (významný prvok odlíšenia „nás“ od „iných“; v rámci cezhraničnej spolupráce aj možnost' posilnenia spoločnej identity a nástroj preklenutia prípadnej nevraživosti). Uvedené štyri funkcie podl'a neho plní každá štátna hranica; rozdiel je v tom, že niektorá môže byt dominantnejšia než ostatné. Hranice totiž vychádzajú z prirodzenej ludskej potreby niekam patrit'; človeku zabezpečujú pocit bezpečia a ochrany.

\section{Charakteristika skúmanej oblasti}

Kysuce ako kultúrny región majú charakter hornatej oblasti na severozápade Slovenska; rozprestierajú sa v povodí rieky Kysuca a jej prítokov. ${ }^{3}$

3 Kysučania ako regionálna skupina a príslušníci daného územného spoločenstva si do súčasnosti udržali silné povedomie regionálnej príslušnosti. 
V minulosti boli súčastou Trenčianskej stolice; v súčasnosti sa tu nachádzajú okresy Čadca a Kysucké Nové Mesto aj niekol'ko obcí žilinského okresu. Región sa prirodzene člení na dolné Kysuce (okolie Kysuckého Nového Mesta), horné Kysuce (údolie riek Čierňanka a Kysuca po Čadcu, respektíve Oščadnicu) a Bystrickú dolinu, ktorá býva vnímaná ako východné Kysuce. ${ }^{4}$ Ako prihraničný región má spoločné (vonkajšie) hranice s dvoma štátmi: na západe s Českom (presnejšie so Sliezskom, iba v krátkom úseku s Moravou - obec Makov a jej osady) a na severe s Pol'skom (pôvodne s Malopol'skom, neskôr Haličou). Sledované územie tak tvorilo (a tvorí) aktívnu kontaktnú zónu viacerých etnických spoločenstiev.

Prvá písomná zmienka o Kysuciach pochádza z 13. storočia, ked'sa začalo osídl'ovanie dolných Kysúc na zvykovom a nemeckom práve. Od druhej polovice 15. storočia bol región postupne kolonizovaný na valaskom práve, pričom za prvú kysuckú osadu, založenú valaskými kolonistami, sa považuje Klubina (prvýkrát písomne doložená v roku 1535). Koncom 16. storočia a v 17. storočí začalo valaské osídlenie prerastat' do kopaničiarskeho osídlenia, čo súviselo so snahami majitel'ov feudálnych panstiev dosídlit podhorské a horské oblasti domácim obyvatel'stvom. Vol'ne migrujúci alebo na salašoch, „cholvarkoch“ či „bačovách“ (v sezónnych pastierskych obydliach s maštalami) žijúci valaskí gazdovia boli aj s rodinami sústred'ovaní na miesta najvhodnejšie na vytvorenie osád. Najstaršou osadou na Kysuciach, ktorá takto vznikla, bola Turzovka (1598) (Beňko 1980: 23-24).

Z konfesionálneho hladiska na Kysuciach dominuje obyvatel'stvo rímskokatolíckeho vierovyznania, z hl'adiska etnicity príslušníci slovenskej národnosti (viac ako $96 \%$ obyvatel'stva), a to aj v hornokysuckých goralských obciach (Skalité, Svrčinovec, Čierne, sčasti Oščadnica a Čadca-Čadečka). Práve jazyková príbuznost' goralského nárečia s polšstinou bola od druhej polovice 19. storočia jedným z argumentov „pol'skosti“ obyvatel'stva kysuckých obcí v údolí rieky Čierňanka a v medzivojnovom období zámienkou na pripojenie daného územia $\mathrm{k}$ Pol'sku. Dialo sa tak napriek tomu, že goralské obyvatel'stvo na Kysuciach sa $\mathrm{z}$ etnického hladiska považovalo (a považuje) za Slovákov (bližšie Kontrik 2013: 139). Hoci český lingvista A. V. Šembera už v roku 1876 tvrdil, že na Kysuciach žilo viac ako 24000 Poliakov, údaje zo sčítania l'udu v Uhorsku z roku 1900 to nepotvrdili. V okrese Čadca uviedlo slovenčinu („,tót") ako svoj materinský jazyk 97,36\% populácie (31 497 z celkového počtu 32365 ), pričom k inému („egyéb“), nešpecifikovanému jazyku (teoreticky aj k polšstine) sa hlásilo $0,5 \%$ (175) obyvatel'stva (Žilinč́́k 2008: 176-177). 4 Jednotlivé subregióny sa navzájom líšia špecifikami v tradičnej kultúre aj
v náreći. 
Charakter osídlenia Kysúc, ich historický vývoj a prírodné podmienky spoločne s d'alšími faktormi formovali tradičnú kultúru regiónu, ktorý býva charakterizovaný ako „chudobný kraj s absolútnou prevahou katolíckeho obyvatel'stva, množstvom veriacich" (Krivý - Balko - Feglová 1996: 218). Vel'ké vzdialenosti a prírodné prekážky spôsobili izoláciu jednotlivých obcí, viedli $\mathrm{k}$ nedostatočným medzilokálnym vztahom a endogamii. Z hl'adiska pol'nohospodárskej produkcie sa rozvíjalo najmä lúčne a lesné hospodárstvo a chov dobytka. Nízka výnosnost' pôdy, neefektívnost' pol'nohospodárstva, ale i pokles významu chovu oviec a dobytka už na začiatku 18. storočia spôsobili, že významným zdrojom obživy sa stala domácka výroba a doplnkové zamestnania, nezriedka spojené s krátkodobou či dlhodobou migráciou obyvatel'stva. K najznámejším doplnkovým zdrojom obživy patrili šindliarstvo, drotárstvo a podomový obchod. V pohraničných obciach malo svoje tradície pašeráctvo do a z Pol'ska, Sliezska a Moravy. Nemožno zabúdat na odchody na sezónne polnohospodárske práce a na vlnu vystahovalectva do USA, Južnej Ameriky a západnej Európy v medzivojnovom období. Po druhej svetovej vojne našli mnohí muži (v menšej miere ženy) zamestnanie v susednom Ostravsku, Tešínsku a Karvinsku.

\section{Hranica ako politikum a priestor mocenských zápasov}

Hranice možno vnímat' ako politikum a prejav moci, pretože vymedzujú priestor organizovanej komunity (štátu) a vydelujú ho od iného (podobne alebo odlišne) organizovaného mocenského priestoru, v rámci ktorého sa vytvárajú špecifické podmienky na rozvoj hospodárstva, kultúry aj politiky. Možno ich považovat' za pomerne dynamicky sa vyvíjajúce veličiny, ktoré sa menia v priestore aj čase. Do polovice 19. storočia slúžili ako mocenský nástroj - vymedzovali územie panovníka a jeho majetok. S prechodom na občiansku spoločnost' sa posilnil význam kultúrnych a spoločenských hraníc a čoraz intenzívnejšie sa formovali religiózne, etnické, jazykové a národnostné hranice. Tam, kde hraničná línia nekorešpondovala s reálnou alebo fiktívnou národnostnou (prípadne religióznou) štruktúrou obyvatel'stva, boli hranice vnímané ako problém (Halás 2002: 50). Pohraničie sa stávalo priestorom mocenských zápasov zainteresovaných štátov a ich územných nárokov. V prípade regiónu Kysuce sa tak dialo v prvých desatročiach 20. storočia na hranici s Pol'skom.

Po skončení prvej svetovej vojny, rozpade Rakúsko-Uhorska a vzniku nástupnických štátov (medzi inými aj Československa a Pol'ska) sa začali prejavovat územné požiadavky Pol'ska na niektoré územia Slovenska. Okrem Oravy a Spiša si nárokovali na oblasti v priestore Čadce (pol'sky označované ako „Czadeckie“), kam po prvýkrát vpadlo pol'ské vojsko už 
začiatkom roka 1919, zničilo čast' železničnej trate medzi Skalitým a Zwardoňom a obyvatel'stvu kysuckých obcí v československo-pol'skom pohraničí zabavovalo dobytok a šatstvo. Ďalšie výpady sa realizovali na jar 1920 v úseku, kde Kysuce hraničili s Tešínskom. Aktívna bola aj propaganda v polskej tlači, ktorá zdôrazňovala pol'ský pôvod obyvatelov Kysúc a zdôvodňovala historické nároky Pol'ska na túto oblast'. Situácia sa upokojila, ked' koncom júla 1920 Konferencia velvyslancov stanovila podobu československo-pol'ských hraníc, ktorá v prípade Kysúc znamenala potvrdenie historickej uhorsko-haličskej hranice z roku 1793 (Žilinč́́k 2008: 177-178).

V 20. rokoch bol styk obyvatelov na oboch stranách hranice bez obmedzení. Rolníci a ich rodinní príslušníci zo Skalitého, Čierneho, Svrčinovca a Oščadnice na slovenskom území, Koniakowa, Jaworzynky, Zwardoňa, Sóly a Horných Rycierok (Rycerka Górna) na polskej strane mali povolený malý pohraničný styk. Ak vlastnili polia, lúky a lesy, ktoré presahovali na územie susedného štátu, smeli obhospodarovat túto pôdu a bez problémov prevážat' úrodu na opačnú stranu hranice. To vytváralo vhodné podmienky na nadväzovanie, upevňovanie a kultivovanie obojstranne výhodných vztahov, uzatváranie manželských zväzkov, rozvoj cezhraničného obchodu aj pašovania ako vedlajšieho zdroja obživy či príjmov.

Nárast napätia v Európe v 30. rokoch 20. storočia znovu oživil pol'ské nároky na severné oblasti Slovenska, vrátane Kysúc. Vztahy medzi Pol'skom a Československom sa vyostrili už v roku 1932, ked'sa pol'ským ministrom zahraničných vecí stal J. Beck, známy svojím radikálnym protifrancúzskym aj protičeským postojom. Na jeseň 1938 pol'ská vláda v reakcii na podpísanie Mníchovskej dohody oficiálne vystúpila s požiadavkou svojho teritoriálneho rozšírenia na úkor oslabeného Československa. V prípade Kysúc si nárokovala na územie, ktorým viedla železničná trat' prechádzajúca stredom obcí Skalité, Čierne a Svrčinovec, čím by sa zabezpečilo dopravné spojenie medzi Zwardoňom a Jablunkovom, ktorý tiež spadal do ich záujmovej oblasti. V konečnom dôsledku boli k Pol'sku inkorporované časti obcí Skalité, Čierne a Svrčinovec (súhrnne 2535 ludí z pôvodných 7234 obyvatelov) a časti katastrálnych území Čadce, Rakovej, Staškova, Olešnej a Turzovky, celkovo asi 45 km² horných Kysúc (Žilinčík 2008: 192). Samotné obyvatel'stvo reagovalo na aktivity zmiešanej pol'sko-československej delimitačnej komisie s nevôlou. Ak je štátna hranica nositel'om ideového vplyvu, ktorý pomáha dotvárat' identity jednotlivcov a spoločenských skupín, navodzuje pocit bezpečia a komfortu, potom násilné zmeny na hraniciach môže civilné obyvatelstvo vnímat' ako zásah do vlastnej integrity a v rámci svojich (neraz obmedzených) možností sa usiluje voči nim vymedzit'.

Intenzívnejšie a emocionálnejšie na náhle (a nechcené) ocitnutie sa na „opačnej“ strane hranice reagovali ženy ako muži, čo dokumentujú za- 
chované písomné pramene aj spomienkové rozprávania. V tejto súvislosti možno uviest' záznam z denníka predsedu slovenskej časti delimitačnej komisie F. Hrušovského z 21. novembra 1938:

\begin{abstract}
„... ked'sme začali zostupovat' do doliny, kde objavovali sa prvé domky Rakovej a Čadce, zbadali nás ludia, ktorí pracovali vonku. [...] Tieto mladé, chudobou, prácou a starostami strhané ženy zo zapadlých dolín najsevernejších Kysúc zrazu vel'kým krikom vyrútili sa na Poliakov, dvíhali svoje hrable a nadávali nevyberaným spôsobom (Vy kurvy pol'ské) - vyhrážajúc sa, že ony Poliakov povraždia, pretože ony do Pol'ska nechcú, že svoje deti do polskej školy posielat' nebudú a radšej svoje deti pobijú." (podl'a Hallon et al. 2012: 16)
\end{abstract}

Sympatie slovenského obyvatel'stva, ktoré sa ocitlo na pol'skom území, ako aj zmiernenie jeho odporu voči polonizácii po zavedení polšstiny ako úradného a vyučovacieho jazyka sa snažili polskí predstavitelia zabezpečit' rozdávaním čerstvého pečiva, kakaa a teplých obedov školopovinným detom, ale aj šatstva, obuvi, vianočných príspevkov a iného sociálne slabým rodinám: „No tak nám dávali tie polské učitel'ky každému hrnček toho kakaa, taký pollitrový, no a ku tomu takú vel'ku bulku pečenú. Jéžiško láskavý, to bola hostina!" (žena, Čierne, podl'a Matula 2012: 178) Kto aj napriek tomu odmietal zapísat' svoje deti do pol'ských škôl a posielal ich do školy v slovenskej časti obce, musel sa obávat' odobratia priepustky potrebnej na prechod hranice, ${ }^{5}$ skonfiškovania majetku a vyhostenia z územia Pol'ska.

Kedže štátna hranica oddeluje územie jedného štátu od druhého, môže byt' vnímaná ako symbol identity obyvatel'stva daného štátu (na základe jeho štátnej /nie etnickej/ príslušnosti). ${ }^{6}$ Podla L. O'Dowda (2002) vyjadruje významný prvok odlíšenia od „tých druhých“. Ak obyvatel'stvo nevníma hranicu ako líniu, ktorá ich oddeluje od „iných“, ale od „vlastných“ (ako v prípade pol'ského záboru severných Kysúc), svoju nespokojnost' môže vyjadrit posielaním protestných nót aj útokmi na symboly novej štátnosti (štátnej príslušnosti), ako hraničné kamene, colné (,,hraničné“) búdky, štát-

5 Pôvodne sa dohodlo právo slobodného pohybu (peši, koňmo, s vozom a podobne) bez zastavovania a povinnosti mat' priepustku alebo cestovný pas na stanovených úsekoch. V polovici januára 1939 sa hranice zatvorili a prechod bol možný iba so špeciálnymi priepustkami (Janík et al. 2015: 19). Tento stav trval do septembra 1939, ked'sa nemeckého taženia proti Pol'sku zúčastnila aj formujúca sa armáda vojnového slovenského štátu a dobrovolníci z radov Hlinkovej gardy. Následne boli k územiu Slovenska pripojené oblasti inkorporované Pol'skom v rokoch 1920 a 1938.

6 K. Popelková a M. Vrzgulová (1998: 98) sa v tejto súvislosti zmieňujú o občianskom aspekte identity. 
ne zástavy, či dokonca atakmi (verbálnymi aj fyzickými) na príslušníkov pohraničnej stráže reprezentujúcej „nechcený“ štát:

„... na druhý deň komisie prišli a chodili s bielymi čapkami a vytyčovali - také lieskové palice, dali tam slamu, a to pobili. Do rána im to ludia preniesli zase na polskú stranu, vždycky im tú hranicu l'udia odsunuli. " (muž, Skalité, podl'a Hallon et al. 2012: 24)

Prípadne: „Jeden ten, volal sa furaj, tak si do krčmy sednul a tam užzmudrovali a - že oni tú búdku prenesú. Prišli a ona bola na tých pražcoch a teraz, že štyria chlapi, že ju odnesú, že to bude len taká, drevený tento... a bol ukotvený. Tak potom od zlosti porozbíjali okná." (muž, Skalité, podl'a Hallon et al. 2012: 24)

V krízových situáciách, ked' (nová) štátna hranica je v rozpore s konceptom domova budovaným po generácie u obyvatelstva žijúceho na území, ktorým prechádza, môže byt' vnímaná ako hrozba, ktorá ich náhle vyčlenila (vykorenila) z ich predchádzajúcej komunity a útočí na ich pôvodnú štátnu, etnickú, sociálnu, kultúrnu, jazykovú a v niektorých prípadoch i lokálnu identitu. Hranica sa v tomto prípade stáva nástrojom sociálnej a kultúrnej exklúzie, ktorá existuje v materiálnej i imaginárnej podobe, fyzickej i kultúrnej forme (porovnaj Popelková - Vrzgulová 1998: 62-100):
„My sme mali chalupu pri železnici, tu na Svrčinovcu, a sme pripadli do Pol'ska. Hned'pol'ská zástava visela, šecko po polsky. A to bolo taký čudný pocit. Fa som od narodenia Slovenka a zrazu, že Polka. Fa som len decko, take devčatko bola, ale sa vo mne šecko burilo. A trvalo to, no... ani nie zrok a sa vratilo. " (žena, 1932, Svrčinovec)

V prípade pamätníkov pol’skej anexie častí okresu Čadca na jeseň 1938 možno konštatovat', že ich subjektívny (vnútorný) pocit etnickej identifikácie odolal tlaku reality, ktorá vyvolávala potrebu rekonštrukcie ich sociálnej identity. ${ }^{7}$ Významnú úlohu v tom však zohrala krátkodobost' pripojenia dotknutého územia $\mathrm{k}$ Pol'sku, a teda nedostatočne dlhé trvanie tlaku na ich asimiláciu (devät' mesiacov).

7 Etnická identita ako súčast' sociálnej identity sa vztahuje na vnímanie súčasných skupinových členstiev, pozícií a rolí jednotlivca. Vo väčšine prípadov je viazaná aj na emocionálne prežívanie svojho vztahu k skupine. Práve emocionálna zložka pomáha rýchlo aktivizovat členov spoločenstva, ktorí sú schopní a ochotní vytvárat' nielen puto solidarity, ale zmobilizovat' sa k určitej akcii (Kiliánová 1998: 11). 
V dejinách kysuckých pohraničných obcí sa objavuje ešte jeden moment, ked' ich novovzniknutá hranica oddelila od príbuzných, známych, ale aj od ich nehnutel'ného majetku, ktorý sa ocitol „na opačnej strane“. Stalo sa tak v dôsledku rozdelenia Česko-Slovenska začiatkom roka 1993, ked' prechod na územie druhého štátu bol možný už len s občianskym preukazom. ${ }^{8}$ Kysučanom to skomplikovalo nielen dochádzanie za prácou do susedného Sliezska, ale život v pohraničí vôbec:

„Fa si pamätám, ako sme šli na gympli na lyžiarsky na Skalité. Serafinov, tušim. Tam bol vlek. A šli sme z Čadce a hned'vo vlaku chodili policajti lebo colníci a chceli po nás občianku, ale my sme šli zo Slovenska na Slovensko. To bolo také fakt zvláštne... No a spolužiačka si zabudla občianku a druhá jej požičala pas, ale v ňom fotka - úplne iný človek, a pustili ju. Ešteže sa potom zrušili hranice a už môžžs cestovat', či do Pol'ska, či do Česka aj d'alej, a nikto t'a nezastavuje." (žena, 1977, Čadca-Horelica)

\section{Hranica ako zdroj príležitostí}

Prihraničné oblasti (regióny) a v rámci nich prihraničné (pohraničné) obce môžu byt' skúmané aj ako určité "translokality", teda viacnásobne a často viacúrovňovo definované miesta, ktoré síce ležia na území jedného štátu, ale zároveň ich charakterizujú vztahy a prepojenia, ktoré ho presahujú (Mikuš 2009: 197). V týchto oblastiach dochádza k viac či menej intenzívnemu kultúrnemu transferu a kontaktom s obyvatel'stvom žijúcim „na druhej strane“ (aj v závislosti od miery priepustnosti hranice), preto hranice nemožno vnímat' ako výlučne geopolitický fenomén; do úvahy treba brat' ich sociálny a kultúrny rozmer. Pokial' hranice nemajú charakter bariéry, plnia funkciu mosta aj zdroja príležitostí (O'Dowd 2002). Vd'aka tomu dochádza $\mathrm{k}$ interakcii procesov vylúčenia a spájania komunít žijúcich na oboch stranách hranice a vytvára sa priestor na využívanie hranice ako zdroja prospechu. Tak tomu bolo v prvej polovici 20. storočia v prípade kysuckých obcí na slovensko-polsko-českom pomedzí, kde malo svoje tradície pašovanie ako doplnkový zdroj príjmov, ale aj v súčasnosti - v prípade cenovo výhodných nákupov potravín, spotrebného tovaru, stavebného materiálu a iného v Česku a Pol'sku.

8 Od roku 1993/1994 bola na česko-slovenskej hranici zavedená pasová kontrola, spočiatku zo strany českej, neskôr aj slovenskej cudzineckej polície. Prvá prenosná montovaná bunka budúcej colnice sa objavila už koncom roka 1992 na českej strane - v obci Most (Mašura 2007). 
Pašovanie prekvitalo v obciach na slovensko-pol'ských (najmä Skalité, Čierne, Krásno nad Kysucou, Oščadnica) aj slovensko-sliezskych/moravských hraniciach (napríklad Vysoká nad Kysucou, Klokočov, Makov, Kornica); vd’aka podomovým obchodníkom, sezónnym pol'nohospodárskym robotníkom a príležitostným priemyselným robotníkom bolo rozšírené aj v Nesluši (hlavne v 40. rokoch). ${ }^{9}$ Išlo o tajné prenášanie tovaru cez hranice $\mathrm{v}$ zmysle importu aj exportu. Táto činnost' sa v rámci jednotlivých lokálnych spoločenstiev nielen tolerovala, ale bola do istej miery vítaná. Vdaka nej sa do oblasti dostával vzácny, nedostatkový alebo lacnejší tovar, prípadne finančné prostriedky nevyhnutné na chod domácnosti i celého hospodárstva. Aj z toho dôvodu sa pašovaniu venovali najmä sociálne slabšie rodiny, ktoré disponovali širokou sietou osobnej podpory - sociálnym kapitálom (Šusteková 2008: 64).

Dejiny pašovania na Kysuciach v prvej polovici 20. storočia môžeme rozčlenit' do piatich etáp, charakteristických stratégiami aj zameraním pašerákov na určité komodity. Prvé obdobie (do roku 1918) je najmenej zmapované vzhl'adom na nedostatok písomných aj ústnych prameňov. Vojnový stav v rokoch 1914-1918 však vyvolal všeobecný nedostatok niektorých druhov potravín (soli, cukru, múky, masla, vajec) a priemyselného tovaru (najmä petroleja), čo viedlo k živelnej aktivite viacerých obyvatelov na vtedajšej uhorsko-haličskej hranici, ktorá mala ešte vnútroštátny charakter. Vd'aka tomu Kysučania nadviazali pracovné a obchodné styky s jednotlivými pol'skými rodinami, ktoré sa v niektorých prípadoch udržali niekol'ko generácií a často boli založené na vzájomných príbuzenských väzbách. Už v tomto období môžeme hladat' korene pašovania koní, kráv a jalovíc z Pol'ska, rozšíreného predovšetkým v neskorších desatročiach.

Po rozpade Rakúsko-Uhorska kontakty medzi obyvatelmi oboch novovzniknutých štátov pretrvali, prípadne sa vytvárali nové, a to aj vd’aka zabezpečeniu malého pohraničného styku medzi obcami ležiacimi na československo-pol'skej hranici. Okrem potravín sa čoraz intenzívnejšie pašoval denaturovaný lieh (v 20. rokoch z Pol'ska, v 30.-40. rokoch z Ostravska a Tešínska) ${ }_{1}^{10}$ nielen pre vlastnú potrebu, ale aj na predaj. Okrem toho sa cez hranice (československo-pol'ské) tajne prepravovali tažné a hospodárske

9 Z obcí na pol'skej strane sa spolupracovalo najmä s obyvatel'stvom Soły v okrese Żywiec (Skalité) a Horných Rycierok (Oščadnica).

10 Jeho pitie bolo rozšírené medzi mladými aj starými. Napriek tomu, že jeho konzumácia mohla mat' pre človeka trvalé zdravotné následky (fyzické aj psychické), zásobovali sa ním nielen na sviatky, ale aj na všedný deň. V najchudobnejších rodinách sa prevarený alebo vodou riedený denaturovaný lieh ponúkal ako pohostenie na pytačkách, zásnubách, svadbách, krstinách, na kare, pri stavbe domu, zbere úrody, na Vianoce či Vel'kú noc. 
zvieratá (najmä kone, hovädzí dobytok, ošípané, menej ovce), čo si vyžadovalo premyslenú organizáciu činnosti. Nevyhnutná bola dobrá znalost' terénu, nelegálnych hraničných priechodov, zvyklostí československej finančnej stráže i pol'ských colníkov (časté boli pokusy o ich podplatenie), ale aj siet' pomocníkov. Tvorili ju predávajúci na druhej strane hranice, ojedinele i „zjednávači“, ktorých úlohou bolo dohodnút výhodnejšiu cenu pre pašeráka; jeden až dvaja prevádzači (respektíve sprievodné osoby, ktoré mali dozerat na hladký priebeh cesty domov a vopred hlásit' prípadný výskyt polskej či československej hliadky); prechovávači pašovaného tovaru; priekupníci, ktorí ho distribuovali d'alej, prípadne priami kupci či objednávatelia (napríklad mäsiari):

„Pašovalo sa vždycky v noci, ked'bola tma. To aby t'a nevideli fiñanci. To bolo tak, vysadli sme na koňa, a tak sme prekročili hranice. A ked' nás začali nahánat', oni aj vol'akedy strielali tí pohraničníci, tí fiňanci, lebo to si nezastavil, to každy utekal inú stranu. A aj tak sa stalo, že si raď̌ej zeskočil z teho koňa, nehal ho tam a bežal si do hory. No a ked'ráno prišli tí strážnici, že odkal'mám v stajni tel'o koní, povedal som, že som ich kúpil od nejakého chlapa lebo že mi ich tam ktosi nehal, ja nevem kto. "(muž, 1924, Krásno nad Kysucou)

Kone sa pašovali na priamu objednávku, prípadne sa ihned' prepravili do vzdialenejších okresov. Pašujúci si vopred či dodatočne zadovážili dobytčie pasy, povinné pre kone i hovädzí dobytok, a zvieratá vol'ne predávali. Rovnaká situácia bola v prípade hovädzieho dobytka (telatá, jalovice, býky alebo kravy) pašovaného z Pol'ska. Ich prevádzaniu na naše územie (najčastejšie cez Skalité) sa v prevažnej miere venovali muži, menej ženy, ojedinele manželské páry. ${ }^{11} \mathrm{O}$ zdravé jalovice a kravy bol záujem nielen zo strany obchodníkov s dobytkom, ale aj sedliakov; telatá a býky sa odpredali mäsiarom. Začiatkom 30. rokov sa v priestupkových protokoloch začali objavovat' záznamy o pašovaní ošípaných. Kým spočiatku išlo o ich nelegálne prenášanie na predaj na Moravu a do Sliezska (v batohu na chrbte), od polovice 30. rokov čoraz častejšie smerovali na Kysuce (spočiatku z Pol'ska, v 40. rokoch z pohraničia protektorátu Čechy a Morava). ${ }^{12}$

Tretie obdobie v dejinách kysuckého pašeráctva sa spájalo s rozpadom Československa a vznikom slovenského štátu. Kým vypuknutie druhej svetovej vojny stážilo pohraničný styk s Pol'skom, v tom čase okupovanom

11 V prípade zadržania pohraničnou hliadkou prítomnost' ženy dodávala vierohodnost' tvrdeniu o hnaní kravy, ktorá pri pasení zablúdila na pol'ské územie.

$12 \mathrm{~V}$ jarných mesiacoch sa pašovali väčšie prasatá určené na zimnú zakálačku, na jeseň niekol'kotýždňové odstavčatá na chov. 
Nemeckom, ${ }^{13}$ rozbitie Československa na jar 1939 zintenzívnilo nezákonnú výmenu tovaru s prilahlými sliezskymi a moravskými oblastami, ktoré sa po mníchovskej dohode (29.-30. septembra 1938) stali súčastou hitlerovského Nemecka, respektíve od marca 1939 protektorátu Čechy a Morava. Najmä kysuckí drotári, podomoví obchodníci, ale aj mládež, muži a ženy, ktorí v rokoch 1939-1945 odchádzali „na roboty“ na "nemecké" či protektorátne územie, predstavovali ideálnu skupinu pašerákov. Na Slovensko prepravovali biče, šnurovačky, črevá na klobásy, kožené remene, perletové gombíky aj denaturovaný lieh. Výnimkou nebol obchod s ríšskymi markami, ktoré na slovenskom území dali do obehu nemeckí vojaci pri tažení proti Pol'sku. Zo slovenskej na „českú "stranu sa vozili potraviny, čo s predlžujúcou sa vojnou malo stúpajúcu tendenciu. Vývoz napokon začal dominovat' nad dovozom. Pašoval sa najmä luxusný tovar, predovšetkým zrnková káva, kakao, čaj, čokoláda, ryža, čierne korenie, mletá červená paprika, rybie konzervy, domáca pálenka, ale aj mlieko, mäso, mäsové výrobky (slanina, salámy a domáce klobásy) a látky (okrem iného kabátový flauš a súkno). Spomenút treba šatstvo (pletené svetre, pánske a nočné košele, spodky, ponožky a iné), obuv (vrátane detských papúč) a podrážkovú kožu. Frekventované boli cigarety a tabak (bližšie Šusteková 2008: 66-67).

V období po skončení druhej svetovej vojny (1945-1948) neexistovali takmer žiadne hraničné obmedzenia (Kiliánová 1992: 63). Vo vojnou postihnutých kysuckých a pol'ských obciach chýbal rozličný tovar a potraviny. Pašovanie soli, zemiakov, fazule, masti či údeného mäsa, ale aj šatstva, látok, obuvi a iných predmetov dennej potreby bolo vítaným zdrojom príjmov pre viaceré rodiny (nielen z obcí bezprostredne susediacich s pol'ským územím, ale aj zo vzdialenejších dedín). Pretrvalo aj pašovanie tabaku na české územie (vrcholiace v rokoch 1945-1947), výrazne zastúpené v aktivitách neslušských „tabačiarok“. ${ }^{14}$ Nakupovali tabak „,na dolniakoch“ (v obci Bajč pri Nových Zámkoch), doma ho rezali na „rezacej mašine" a napchali do špeciálne ušitých košiel' a spodničiek tak, že žena, ktorá si ich obliekla, vyzerala ako tehotná: „Mama chodili na tabak a ja s tabakom. "(žena, 1928, Nesluša) Svoj tovar ponúkali hlavne v Pardubiciach, Hornej a Dolnej Bráne, Starej a Novej Pake, ale i v Podmoklí, kam cestovali vlakom. Obvykle chodili k známym, ktorí im sprostredkovali odpredaj tabaku. Najčastejšie ho vymieňali za predmety dennej potreby, ktorých bol na Slovensku nedostatok (šatky, plachty, postel'ná bielizeň, látky, deky, hrnce). Čast' predmetov si ponechali, čast' na južnom Slovensku opät' vymenili za tabakové listy.

13 Kým severné oblasti Kysúc boli pripojené k Pol'sku, v rámci pašovania sa využívalo, že čast' príbuzných a známych sa ocitla na opačnej strane hranice.

14 Neskôr sa záujem o tabak zo strany českého obyvatel'stva začal znižovat', zárobky nezodpovedali vynaloženému úsiliu a ženy od jeho pašovania ustúpili. 
Obdobie po februárovom prevrate 1948 bolo charakteristické spoločensko-politickými zmenami súvisiacimi s nástupom komunistickej diktatúry. Hoci Pol'sko aj Československo patrili ku krajinám Východného bloku, režim na spoločných hraniciach bol prísny. Pašovanie sa stalo záležitostou turistov, ktorí do Pol'ska načierno vyvážali cukrovinky, čokoládu, alkohol, zipsy, od polovice 60. rokov dederónové košele, dámske a detské pančuchy. Obyčajne sa predávalo za autobusom alebo v skrytých uličkách; potenciálni kupci mohli byt' oslovení aj priamo na ulici. Praktickejšie bolo mat' vytipované rodiny, ktoré vopred oznámili, o čo by mali záujem (Rogulová 2003: 37). Takto získané zloté sa použili na nákup postel'nej bielizne, svetrov z ovčej vlny, kožuchov, kávových a čajových súprav, cukríkov („,kroviek“), zavše aj detských topánok, šiat, šatiek a podobne. Obyvatelia Skalitého nad'alej využívali staré pašerácke priechody na dovoz umelých vianočných stromčekov, detských koč́kov, ale aj zemiakov, ktoré pestovali na poliach, patriacich k Pol'sku. ${ }^{15}$

Niektorí obyvatelia Oščadnice, ale aj Čierneho ešte v druhej polovici 20. storočia pašovali býky, jalovice a kone z Pol'ska:

„Na polsko-slovenskej hranici neboli ploty s ostnatým drôtom ako na západe, ale mali sme tu orané medze, cez ktoré nesmel nikto prejst. Ale miestni sa vynašli a obchodovali aj tak. Poliaci mali aj počas socializmu svoje gazdovstvá, hoci pracovali vo fabrikách. Naši od nich kupovali kravy. Predávajúci priviedol k vyoranej medzi na pol'skú stranu asi šest'kráv a slovenský záujemca z dial'ky vyberal. Poliak potom šibol kravu a tá prešla na Slovensko. Potom sa dohodli, pod ktorým kameňom nechá kupujúci peniaze. Pol'ské kravy sa dali na slovenskej paši pol'ahky spoznat': všetky boli červené. Ale nikoho takýto druh obchodu netrápil, nikto nemal potrebu niekoho udávat'. " (cit. podl'a Szalayová 2020)

Ešte v roku 1994, ked' sa opät' umožnil malý pohraničný styk medzi Slovenskom a Pol'skom, sa okrem alkoholu (do Pol'ska) pašovali kone (na Slovensko). ${ }^{16}$ Niektoré ženy sa vrátili k pašovaniu tabakových výrobkov - tentokrát z Pol'ska na Slovensko, pričom využili špeciálne upravené podväzkové pásy, ako aj odev doplnený početnými vnútornými vreckami. Do Česka sa chodil nakupovat' lacný alkohol (vrátane konzumného lie-

15 Na slovenskú stranu ich skotúlali dole kopcom a následne pozbierali.

16 V tom čase slovenskí priekupníci skupovali jatočné kone v Česku a prepravovali ich do Pol'ska (odtial' sa vyvážali najmä do Talianska). Ako protihodnotu kysuckí pašeráci dostávali tažné kone, ktoré sa používali (predávali) na prácu v lesoch. 
hu). Blízkost' štátnej hranice (s Českom aj Pol'skom) pre prihraničné obce znamenala vybudovanie charakteristického typu občianskej vybavenosti (cestné a železničné komunikácie, colnice, parkoviská, zmenárne, obchody, reštauračné a ubytovacie zariadenia, tržnice - „pol'ské trhy“ a iné); zároveň sa vytvorili predpoklady na tranzit ludí a tovaru. Česko je aj v súčasnosti vnímané ako zdroj pracovných príležitostí (najmä pre zdravotnícky personál) a zároveň sa stalo potenciálnym odbytiskom domácej produkcie obyvatel'ov Kysúc. Pol'sko je oblúbenou destináciou nákupného turizmu, orientovaného na lacné potraviny (mäso, mäsové a mliečne výrobky, vajcia, ryby, cukrovinky, zemiaky, kapusta, strukoviny, ovocie) ${ }^{17}$ stavebný materiál, sanitu, nábytok, záhradkárske potreby, vianočné stromčeky, odev a obuv: „Polaci sú rodeni obchodnici. Tam nemaš problem si cenu zjednat'- hned" ti zrobi cenu. "(muž, 1969, Oščadnica) Vyhl'adávané sú aj zubné ambulancie v Pol'sku (napríklad vo Wapieniciach pri Bialsku-Bialej) a Česku (najmä v Mostoch u Jablunkova, Jablunkove či Třinci), ktoré slovenskej klientele ponúkajú cenovo výhodné ošetrenie zubov, ale aj niektorí lekári - špecialisti (Jablunkov, Třinec).

Ked' začiatkom jari 2020 vypukla prvá vlna pandémie COVID-19 a bolo nevyhnutné uzavriet' hranice s Pol'skom a Českom, niektoré obce (napríklad Čierne) nechali na vlastné náklady vysypat na cesty v blízkosti hraníc kopy štrku, aby obyvatel'stvu zabránili vycestovat' do susednej republiky (najmä za nákupmi, ale aj kvôli návšteve príbuzných a podobne) ${ }^{18} \mathrm{Aj}$ z toho dôvodu sa na sociálnych sietach a v rôznych diskusných fórach začali objavovat' príspevky, v ktorých si zainteresovaní radili, ako obíst' tieto opatrenia, kadial' sa dá dostat' do Pol'ska či Česka (a spät' na Slovensko) bez rizika hraničnej či policajnej kontroly, či následnej povinnej karantény: „Zdravím, ako je to teraz na hraniciach $z \breve{C} R$ ? Je pravda, že kontrolujú? Potrebujem vybavit' čosi naotočku a nechcem skončit' v karanténe. Šiel teraz niekto cez Bílu, aká je tam cesta?" (muž, 30. 4. 2020); „Ahojte, máte niektorá teraz zubára v ČR? Ako je to s prechodom cez hranice, aby sme nemuseli do karantény? Ďakujem. "(žena, 26. 9. 2020) Počas druhej vlny pandémie sa začali objavovat' aj príspevky ohl'adne možnosti/nemožnosti nákupov v susedných štátoch, napríklad:

17 Okrem trhov v Zwardoni a „polskom Tešine“" (Cieszyn) obyvatel'stvo nakupuje v tamojších kamenných (v súčasnosti aj internetových) obchodoch a vel'koskladoch. Medzi populárne patrí siet' supermarketov Biedronka. „Polský" tovar ponúkajú aj ambulantní predajcovia, pravidelne alebo príležitostne predávajúci v niektorých obciach (napríklad pred obecným úradom alebo kultúrnym domom - v stánku alebo pojazdnej predajni), prípadne na „pol'ských trhoch“ v Oškerde (okres Kysucké Nové Mesto).

18 Majitelia terénnych vozidiel a štvorkoliek tieto bariéry obchádzali po prilahlých trávnatých plochách a poliach. 
„Prosim vás, ako to vyzerá v Pol'sku, je už otvorena castorama a obchodné domy? Sú kontroly na hraniciach? D̃akujem za info. " (žena, 14.12.2020)

Potvrdzuje sa, že intenzívne kontakty medzi obyvatel'mi prihraničných oblastí (v nekonfliktnej situácii), založené na ekonomických, príbuzenských, spoločenských aj iných väzbách, nevedú k zániku hraníc (v tomto prípade štátnych aj etnických), ale spôsobujú, že už nie sú bariérami, ale hraničnými a zároveň spojovacími miestami. Osobný kontakt a spolupráca ludí z „oboch strán“ vedie $\mathrm{k}$ zmenšovaniu predsudkov a relativizácii stereotypných predstáv, ako aj k pozitívnym postojom a tolerancii. Premieta sa aj do kooperácie lokálnych politických, administratívnych a obchodných elít, najmä v podobe projektov cezhraničnej spolupráce, ktorých cielom je umožnit' financovanie aktivít, ktoré prehlbujú vzájomné kontakty regiónov so spoločnou medzištátnou hranicu (takzvaných „euroregiónov“).

\section{Záver}

Príspevok sa na príklade regiónu Kysuce, ktorý hraničí s Pol'skom aj Českom, snažil poukázat' na vybrané aspekty života na hranici v minulosti. Zameral sa na problematiku hranice ako bariéry, ktorá oddeluje dva štáty a ich obyvatel'stvo, súčasne však môže predstavovat isté spojivo - priestor, kde dochádza k obojstranným kontaktom, intenzívnej kultúrnej výmene, ekonomicky prospešným aktivitám, ale aj k žitiu a aktívnemu manifestovaniu etnickej, sociálnej, lokálnej, regionálnej a štátnej identity obyvatel'stva na danom území. Hranice totiž za každých okolností existujú objektívne - vo fyzickej realite, ale aj subjektívne - v hlavách ludí. Spomienkové rozprávania venované „krízovému stavu“, ústiacemu v rokoch 1938-1939 do inkorporovania častí prihraničných obcí Skalité, Svrčinovec a Čierne Pol'skom, dokladajú, že sebadefinícia jedinca i definícia z pohl'adu ostatných členov spoločenstva sa často viaže na etnickú identitu a etnickú pamät'. Štátne hranice sa stávajú „hranicami identity“, a to vrátane jej etnického (príslušnost' k národu), teritoriálneho (príslušnost' k lokalite) aj občianskeho aspektu (príslušnost' k štátu).

Krátkodobé pripojenie severných oblastí okresu Čadca k pol'skému územiu v súčasnosti nerezonuje ako krivda v kolektívnom vedomí (historickej pamäti) Kysučanov, kedže okrem pamätníkov (a ich rodinných príslušníkov) má informácie o tejto udalosti iba minimálna čast' obyvatel'stva. Na prípadný pocit krivdy pomáhali zabudnút aj zaužívané mechanizmy medziskupinových sociálnych vztahov, založené na vzájomnom profitovaní z pašovania nedostatkového tovaru z/do Pol'ska. Slovensko-pol'ské hranice od roku 1918 do roku 1945 neboli iba miestom mocenských sporov, ale aj „mostom“ a „zdrojom príležitostíc. Do súčasnosti túto funkciu 
plní aj česko-slovenská hranica, ktorá v rokoch 1918-1939 a 1945-1993 de facto neexistovala. Obyvatel'stvo mohlo bez väčších obmedzení prechádzat' „na druhú stranu“, čo dokladajú návštevy jarmokov, pútnických miest a odchody za prácou na sliezske/moravské/české územie, ale aj zmiešané manželstvá a chalupy a chaty, ktoré vlastnili (sčasti vlastnia) českí občania na kysuckých kopaniciach. Rozdelenie Česko-Slovenska v roku 1993 a následné prepúštanie časti Kysučanov (dovtedy pracujúcich na Ostravsku) zo zamestnania tieto vzt́ahy nakrátko naštrbilo, v súčasnosti (v podmienkach schengenského priestoru) je hranica vnímaná ako priestor vzájomnej spolupráce v politickej, kultúrnej aj ekonomickej oblasti. Aj to je dôvod, prečo výskum v tejto oblasti nepovažujeme za ukončený. $\mathrm{V}$ budúcnosti sa chceme zamerat' na otázky cezhraničnej spolupráce a jej reflexiu obyvatel'stvom na oboch stranách hranice.

fúl 2021

\section{Literatúra a pramene}

Beňko, Ján. 1980. Osídlenie Kysúc. In: Sprázy a informácie (Kysucké múzeum) 4. Čadca: Kysucké múzeum v Čadci: 5-58.

Duleba, Alexander et al. 2017. Hranice a cezhraničná spolupráca. Úvod do výskumu hraníc. Prešov: Prešovská univerzita v Prešove.

Halás, Marián. 2002. Hranica a prihraničný región v geografickom priestore (teoretické aspekty). In: Bezák, A. (ed.): Geographia Slovaca 18. Luknišov zborník 3. Bratislava: Geografický ústav SAV: 49-55.

Hallon, Ludovít et al. 2012. Kysuce v 20. storočí. Čadca: Kysucké múzeum v Čadci; Bratislava: Historický ústav SAV.

Janík, Mário et al. 2015. Kysuce 1938-1945. Čadca: Kysucké múzeum v Čadci.

Kiliánová, Gabriela. 1992. Vztah lokálneho spoločenstva k štátu a jeho odraz v hierarchii hodnôt (na príklade pašovania cez hranicu). In: Zmeny $v$ hodnotozých systémoch v kontexte každodennej literatúry. Výsledky výskumov v roku 1992. Bratislava: Národopisný ústav SAV: 58-65.

Kiliánová, Gabriela. 1998. Determinanty etnickej identity. Na príklade etnických spoločenstiev na hranici. (Niekol'ko úvodných poznámok do diskusie). Etnologické rozprayy 3, 2: 6-12.

Kontrik, Alojz. 2013. Gorali na Kysuciach. In: Gorali. Velká kniha o goraloch Oravy, Liptova a Kysúc. Martin: Matica slovenská: 135-164.

Krivý, Vladimír - Feglová, Viera - Balko, Daniel. 1996. Slovensko a jeho regióny. Sociokultúrne súvislosti volebného správania. Bratislava: Nadácia Médiá. 
Mašura, Marek. 2007. Česko-slovenská hranica opät' zanikne. Pravda [online]. [2021-02-12]. Dostupné z: https://spravy.pravda.sk/domace/ clanok/156173-cesko-slovenska-hranica-opaet-zanikne/.

Matula, Pavol. 2012. Školské a cirkevné pomery na Kysuciach odstúpených Pol'sku v roku 1938. In: Historia nova 5. Štúdie k výročiu fána Kollára. Bratislava: Univerzita Komenského: 176-195. Dostupné z: http:// www.fphil.uniba.sk/fileadmin/user_upload/editors/ksd/Hino5.pdf.

Mikuš, Marek. 2009. Naprieč hranicami, mimo autentického a falošného: transnacionálna antropológia, turizmus a identita. Sociální studia 6, 1: 193-216. https://doi.org/10.5817/SOC2009-1-193

O'Dowd, Liam. 2002. The Changing Significance of European Borders. Regional \& Federal Studies 12, 4: 13-36.

Popelková, Katarína - Vrzgulová, Monika. 1998. Vrbovce, osada Sabotovci - permanentný život na hranici (k problematike procesov tvorby etnickej identity). Etnologické rozprazy 5, 2: 62-100.

Rogulová, Jaroslava. 2003. Pašerácke dobrodružstvá v socializme. História 3, 3: 37.

Šusteková, Ivana. 2008. Pašovanie ako špecifické doplnkové zamestnanie na Kysuciach v prvej polovici 20. storočia. In: Zborník Kysuckého múzea v Čadci 11. Čadca: Kysucké múzeum v Čadci: 62-82.

Szalayová, Erika. 2020. Ako to vyzerá na mieste, kde sa stretávajú tri krajiny? Česi sa nám vysmievajú! Život [online]. [2021-02-12]. Dostupné z: https://zivot.pluska.sk/reportaze/ako-to-vyzera-mieste-kde-stretavaju-tri-krajiny-cesi-nam-vysmievaju.

Žilinčík, Ivan. 2008. Obsadenie častí Kysúc Pol'skom v novembri 1938 ako vyvrcholenie pol'ských územných nárokov v medzivojnovom období 20. storočia. In: Zborník Kysuckého múzea v Čadci 11. Čadca: Kysucké múzeum v Čadci: 175-200. 